\title{
Dehydroepiandrosterone in Relation to Adiposity, Glucose Tolerance and Lipid Spectra in Czech Non-Diabetic Population
}

\author{
B. BENDLOVÁ, J. VRBÍKOVÁ, M. HILL, M. VAŇKOVÁ, P. LUKÁŠOVÁ, J. VČELÁK, \\ D. VEJRAŽKOVÁ, K. DVOŘÁKOVÁ, R. HAMPL, K. VONDRA, L. STÁRKA
}

Institute of Endocrinology, Prague, Czech Republic

Received November 12, 2007

Accepted January 28, 2008

On-line February 13, 2008

\begin{abstract}
Summary
This study aimed to examine relationships between DHEA(S), anthropometric parameters, oral glucose tolerance test derived data and lipid spectra in a Czech non-diabetic population. 380 healthy volunteers both with and without a family history of diabetes type 2 (DM2) were enrolled into the study (women: $\mathrm{n}=235$, age $28.9 \pm 9.4$ years, BMI $22.3 \pm 4.5 \mathrm{~kg} / \mathrm{m}^{2}$, men: $\mathrm{n}=145$, age $32.3 \pm 10.0$ years, BMI $24.7 \pm 3.6 \mathrm{~kg} / \mathrm{m}^{2}$ ). Spearman's correlations (both without and with the adjustment for age, age and BMI), as well as ANCOVA were used. Non-adjusted data showed many "beneficial" correlations between DHEA(S) and both anthropometric and metabolic variables. Statistical analysis revealed that almost all correlations of DHEA(S) to adiposity and fat distribution in men as well as in women disappeared after the adjustment. There are, however, differences between men and women in the correlation of $\operatorname{DHEA}(S)$ to insulin sensitivity and lipid levels. The use of hormonal contraceptives (COC) is also an important factor in this relationship. In men and also in women using COC, DHEA-S after adjustment correlated positively with fasting and stimulated glucose, insulin and C-peptide, and negatively with insulin sensitivity. In this respect, the benefit of DHEA(S) supplementation seems - at least in terms of its alleged antiobesity and antidiabetogenic effects - to be more than controversial.
\end{abstract}

\section{Key words}

Dehydroepiandrosteroine • Obesity • Lipids • Insulin resistance • Sex hormones

\section{Corresponding author}

B. Bendlová, Institute of Endocrinology, Národní trída 8, 11694 Prague 1, Czech Republic. E-mail: bbendlova@endo.cz

\section{Introduction}

Dehydroepiandrosterone (DHEA) and its sulfate (DHEA-S) are major adrenal secretory products in humans, but their multiple biological 'genomic' and 'non-genomic' pathways have yet to be fully explained (Hampl and Stárka 1998). These 'inactive' precursor steroids are converted into active androgens and estrogens in peripheral target tissues, allowing the local regulation of active steroid levels on a cellular basis (Labrie 1991). In addition, DHEA is converted in various tissues to further biologically active metabolites, of which 7-oxo-derivatives exert thermogenic properties and as such they may even simulate thermogenic effects of thyroid hormones (Hampl et al. 2006a). Our recent report demonstrated that administration of 7-oxodehydroepiandrosterone may temporarily affect thyroid hormone levels (Hampl et al. 2006b). This was also the reason that, among other parameters, we were measuring thyroid hormone levels in this study.

The marked age-related decline in serum DHEA and DHEA-S levels both in men and women suggests that a relative deficiency of these steroids may be causally related to the development of diseases associated with aging, such as insulin resistance, obesity, cardiovascular disease and others (Tchernof and Labrie 2004, Baulieu et al. 2000, Celec and Stárka 2003).

Indeed, most non-human studies have reported the favourable antiobesity, antidiabetic and antiatherogenic, immunoprotective and antiglucocorticoid effects of DHEA(S) (Kroboth et al. 1999). The results from rodent experiments, however, are not relevant to human beings because of the physiologically low circulating DHEA(S) levels in rodents. Nevertheless, beneficial effects have also been found in human intervention studies with DHEA in doses of 25-1600 $\mathrm{mg}$ /day (Villareal and Holloszy 2004, Nestler et al. 1988, Welle et al. 1990). Administration of exogenous 
DHEA(S) increases predominantly estrogen levels in men and androgens in women, so the outcome of DHEA treatment may depend on the initial hormonal milieu (Cameron and Braunstein 2005).

Some human studies have reported a negative correlation of DHEA(S) to BMI, fat distribution and insulin resistance. There are also studies that have supported a link between a higher DHEA/DHEA-S ratio and a favorable lipid profile. The outcomes, however, are often controversial and the results of most studies have not been adjusted for age or other confounding factors, as reviewed by (Tchernof and Labrie 2004). The objective in this study was to assess correlations of DHEA and DHEA-S levels to anthropometric measurements and to biochemical and hormonal parameters related to glucose and lipid metabolism in Czech population both prior to and after adjustments for age or for age and BMI.

\section{Methods}

The study enrolled 380 healthy volunteers (women: $\mathrm{n}=235$, age $28.9 \pm 9.4$ years, BMI $22.3 \pm 4.5$ $\mathrm{kg} / \mathrm{m}^{2}$, men: $\mathrm{n}=145$, age $32.3 \pm 10.0$ years, BMI $24.7 \pm 3.6$ $\mathrm{kg} / \mathrm{m}^{2}$; mean $\pm \mathrm{SD}$ ) with/without family history of diabetes type 2 (DM2). The subjects took no medication, except for low dose combined hormonal contraceptives (COC) in 110 women.

After signing written consent approved by the local Ethical Committee, the subjects fasted overnight and then underwent a 3-hour oral glucose tolerance test (oGTT). There was a sampling for blood glucose (gly), insulin (ins) and C-peptide (Cpep) before the $75 \mathrm{~g}$ glucose oral load and after 30, 60, 90, 120, 150 and $180 \mathrm{~min}$. Free fatty acids (FFA) were measured at 0 and 180 mins. The lipid spectrum, steroid and thyroid hormones, IGF1, adipocytokines and glycated proteins were determined in the basal sample.

Body weight and height, as well as other anthropometric measures were determined. Body mass index (BMI), waist to hip ratio (WHR) and body composition were calculated using ANTROPO software (Bláha 1991).

Blood glucose was determined by the glucose oxidase method (Beckman Glucose Analyzer 2). Insulin was estimated using IRMA kit (Ins, Immunotech, Marseilles, France). Serum levels of C-peptide were evaluated using IRMA kit (Cpep, Immunotech, Czech Rep.). Glycosylated proteins were determined by spectrophotometric redox reaction. Total cholesterol
(total-CH, Merckotest, CHOD-PAP Method), highdensity lipoprotein cholesterol (HDL-CH, Merck System Cholesterin, CHOD-PAP Method) and triacylglycerol (TG) concentrations (Merck System, GPO-PAP-Method) were measured in serum using a Merck Vitalab Eclipse analyser. Low-density lipoprotein cholesterol (LDL-CH) levels were calculated as: $\mathrm{LDL}-\mathrm{CH}=$ total- $\mathrm{CH}-(\mathrm{TG} / 2.2)$ HDL-CH. Total FFA was determined by the spectrophotometric method using NEFA-C-ACS-ACOD (Wako Chemicals GmbH, Germany). The spectra of fatty acids were analysed by gas chromatography (GC-14A Instrument with FID, Shimadzu, Kyoto, Japan) after extraction and subsequent derivatization by isooctanemethylchloroformate $(5: 1)$, heptadecanoic acid was used as an internal standard.

Dehydroepiandrosterone and DHEA-S, testosterone $(\mathrm{T})$, androstenedione (A), and sex hormonebinding globulin (SHBG) were determined by radioimmunoanalytical assays as described in (Šulcová et al. 1997, Vrbíková et al. 2001). Leptin was determined by RIA kit (Linco Res. Inc., St. Charles, Missouri, USA). Adiponectin was determined by ELISA kit (Linco Res. Inc., St. Charles, Missouri, USA). Insulin-like growth factor 1 (IGF1) was determined by IRMA kit after prior dissociation from its binding proteins (Immunotech, CR).

$\mathrm{TSH}$, free T3 and free T4 were measured by the electrochemiluminiscent method, using an Elecsys 2010 automatic analyser (Hitachi-Boehringer, Mannheim, Germany).

For the evaluation of insulin sensitivity and betacell function, the indices derived from fasting and oGTT measurements were calculated as follows: HOMA R (ins0 x gly0/22.5), SUMA ins (ins0 + ins60 + ins120), FGIR (gly0/ins0), Matsuda index $=10,000 / \sqrt{ }$ (gly0 $x$ ins0 $\left.x G_{\text {mean }} \times I_{\text {mean }}\right)$, where $G_{\text {mean }}\left(I_{\text {mean }}\right)$ is the mean of blood glucose (insulin) levels during oGTT, AUCgly/AUCins and HOMA F $(20 \mathrm{x}$ ins0/(gly0-3.5)) (Matthews et al. 1985, Matsuda and De Fronzo 1999).

\section{Statistics}

Robust Spearman's correlation analyses, including partial correlations with adjustment to constant age, age and BMI was applied to evaluate the relationships between DHEA, DHEA-S and anthropometric parameters, oGTT derived parameters, lipid spectra and other hormonal and metabolic parameters. Given that COC could influence any of the observed parameters, women were analysed separately according to COC use. ANCOVA was used for the 
evaluation of the differences between groups. Statistics were calculated using the NCSS 2004 (USA) and Statgraphics plus v.5.1 Manugistic (Rockville, USA) software packages.

\section{Results}

DHEA(S) levels in study subjects - influence of hormonal contraceptives but not family history of diabetes type 2

Given the sex dependency of DHEA and DHEA$S$ levels, men and women were evaluated separately. DHEA(S) levels in men and in women were divided into two subgroups, $\mathrm{COC}$ users and $\mathrm{COC}$ non-users are given in Table 1. COC non-users were significantly older than women using COC. After the adjustment for age and BMI the DHEA-S as well as DHEA levels were significantly lower in women using COC (both $\mathrm{p}<0.001$ ). Regarding family history of DM2, neither DHEA nor DHEA-S levels after adjustment for age, or for age and BMI, differed between subjects with or without family history of DM2 (data not shown). The subjects both with and without family history of DM2 were therefore considered together for further analysis.

Correlations of non-adjusted DHEA(S) levels to anthropometric data, oGTT derived parameters, lipids and steroids

Women (Table 2a): In COC non-users, DHEA correlated negatively to age $(\mathrm{p}<0.001)$, BMI $(\mathrm{p}<0.01)$, waist circumference $(p<0.001)$, WHR $(p<0.001)$ and percentage of fat mass $(p<0.05)$. There was no correlation found in COC users between DHEA and anthropometric parameters (data not shown). A negative correlation between DHEA and fasting blood glucose $(\mathrm{p}<0.001)$ was found in COC non-users. For blood glucose after oral glucose load, negative correlations were present, the strongest being between DHEA and gly120 $(\mathrm{p}<0.01)$. No correlations for insulin and C-peptide values were observed regardless $\mathrm{COC}$ use. A negative correlation to glycosylated proteins $(r=-0.23, p<0.01)$ was found only in COC users. For lipid levels, DHEA of COC non-users correlated positively to HDL-CH $(\mathrm{p}<0.01)$ and negatively to LDL-CH $(\mathrm{p}<0.001)$. In women using $\mathrm{COC}$, no correlations of DHEA to any of lipid parameters were found. DHEA correlated positively to testosterone, androstendione (all $\mathrm{p}<0.001$ ) irrespectively of COC. DHEA did not correlate to SHBG. A positive correlation to IGF1 $(p<0.001)$ was found only in women that did not use COC.

Non-adjusted DHEA-S correlated negatively to age in women $(\mathrm{p}<0.001)$. No correlation to anthropometric data was found. In COC non-users, no correlation to oGTT derived parameters was found, except for a weak positive correlation to fasting and stimulated blood glucose $(p<0.05)$. In the subgroup of women using $\mathrm{COC}$, however, positive correlations of DHEA-S to fasting and stimulated C-peptide (Cpep0, $\mathrm{r}=0.24, \mathrm{p}=0.006$; Cpep90, $\mathrm{r}=0.20, \mathrm{p}=0.02$; Cpep120, $\mathrm{r}=0.24, \mathrm{p}=0.007$ ) and insulin levels (ins0, $\mathrm{r}=0.23$, $\mathrm{p}=0.009 ; \quad$ ins $90, \quad \mathrm{r}=0.29, \mathrm{p}=0.001 ; \quad$ ins120, $\mathrm{r}=0.31$, $\mathrm{p}=0.0007$ ), and a negative correlation to insulin sensitivity (Matsuda, $\mathrm{r}=-0.36, \quad \mathrm{p}=0.0006$; AUCgly/AUCins, $\mathrm{r}=-0.41, \mathrm{p}=0.0007$; FGIR, $\mathrm{r}=-0.25$, $\mathrm{p}=0.004 ; 1 /$ HOMAR, $\mathrm{r}=-0.21, \mathrm{p}=0.02$ ), were found. In women without COC, DHEA-S correlated negatively to LDL-CH $(\mathrm{p}<0.01)$ and positively to HDL-CH $(\mathrm{p}<0.05)$, but these correlations were not found in the COC subgroup. DHEA-S correlated negatively to SHBG levels $(p<0.05)$ in both subgroups. Correlations to steroids (all $\mathrm{p}<0.001$ ) were similar to those for DHEA, positive correlation to IGF1 $(\mathrm{p}<0.01)$ was found only in COC non-users.

Table 1. Characterization of study subjects with respect to age, BMI and DHEA(S) levels.

\begin{tabular}{llll}
\hline Parameter & $\begin{array}{l}\text { WOMEN } \\
\text { COC non-users }\end{array}$ & $\begin{array}{l}\text { WOMEN } \\
\text { COC users }\end{array}$ & MEN \\
\hline Number & 125 & 110 & 145 \\
Age $($ years $)$ & $31.6 \pm 9.9^{\mathrm{a}}$ & $26.4 \pm 8.8^{\mathrm{a}}$ & $32.2 \pm 10.1$ \\
BMI $\left(\mathrm{kg} / \mathrm{m}^{2}\right)$ & $23.3 \pm 4.8^{\mathrm{b}}$ & $22.9 \pm 4.2^{\mathrm{b}}$ & $24.7 \pm 3.6$ \\
DHEA $-\mathrm{S}(\mu \mathrm{mol} / \mathrm{l})$ & $5.1 \pm 2.9^{\mathrm{b}}$ & $4.5 \pm 2.6^{\mathrm{b}}$ & $7.4 \pm 3.4$ \\
DHEA (nmol/l) & $22.1 \pm 15.1^{\mathrm{b}}$ & $20.2 \pm 13.4^{\mathrm{b}}$ & $23.9 \pm 11.3$ \\
\hline
\end{tabular}

COC - combined oral contraceptives

${ }^{a}$ ANCOVA $p<0.001 ;{ }^{b}$ ANCOVA (adjusted for age and BMI) $p<0.001$ 
Table 2a. Spearman's correlations of DHEA(S) levels with anthropometric data, oGTT derived parameters, lipids and steroids in women (COC non-users).

\begin{tabular}{|c|c|c|c|c|c|c|c|c|c|}
\hline \multicolumn{3}{|c|}{ Anthropometry } & \multicolumn{7}{|c|}{ oGTT } \\
\hline Age & Waist & WHR & BMI & $\begin{array}{l}\text { Muscle } \\
\text { mass \% }\end{array}$ & $\begin{array}{l}\text { Fat } \\
\text { mass\% }\end{array}$ & Gly0 & Gly60 & Gly90 & Gly120 \\
\hline
\end{tabular}

DHEA-S

\begin{tabular}{llllllll}
\hline & & & & -0.20 & -0.19 & -0.18 \\
Non-adjust. & -0.48 & & & & 0.02 & 0.04 & 0.05 \\
& $<0.001$ & & & & & \\
Adj.for age & & 0.19 & 0.18 & 0.26 & & \\
Adj.for age & 0.03 & 0.04 & 0.004 & & \\
and BMI & & & & &
\end{tabular}

\section{DHEA}

\begin{tabular}{lllllllllll}
\hline \multirow{2}{*}{ Non-adjust. } & -0.6 & -0.3 & -0.33 & -0.23 & 0.16 & -0.18 & -0.23 & -0.18 & -0.21 & -0.24 \\
& $<0.001$ & $<0.001$ & $<0.001$ & 0.008 & 0.06 & 0.04 & $<0.001$ & 0.04 & 0.02 & 0.008
\end{tabular}

Adj. for age

Adj. for age

and $B M I$

\begin{tabular}{|c|c|c|c|c|c|c|c|}
\hline & \multicolumn{3}{|l|}{ Lipids } & \multicolumn{3}{|l|}{ Steroids } & \multirow{2}{*}{$\begin{array}{l}\text { Other parameters } \\
\text { IGF1 }\end{array}$} \\
\hline & HDL-CH & LDL-CH & FFA0 & SHBG & $\mathbf{T}$ & $\mathbf{A}$ & \\
\hline \multicolumn{8}{|l|}{ DHEA-S } \\
\hline \multirow{2}{*}{ Non-adjust. } & 0.21 & -0.27 & & -0.18 & 0.45 & 0.51 & 0.29 \\
\hline & 0.02 & 0.003 & & 0.04 & $<0.001$ & $<0.001$ & $<0.001$ \\
\hline \multirow{2}{*}{ Adj. for age } & & & 0.19 & -0.24 & 0.37 & 0.37 & \\
\hline & & & 0.05 & 0.006 & $<0.001$ & $<0.001$ & \\
\hline Adj. for age & 0.19 & & 0.20 & -0.18 & 0.40 & 0.37 & \\
\hline and BMI & 0.04 & & 0.04 & 0.05 & $<0.001$ & $<0.001$ & \\
\hline \multicolumn{8}{|l|}{ DHEA } \\
\hline \multirow{2}{*}{ Non-adjust. } & 0.24 & -0.41 & & & 0.47 & 0.57 & 0.30 \\
\hline & 0.007 & $<0.001$ & & & $<0.001$ & $<0.001$ & $<0.001$ \\
\hline \multirow{2}{*}{ Adj. for age } & & -0.22 & & & 0.38 & 0.40 & \\
\hline & & 0.014 & & & $<0.001$ & $<0.001$ & \\
\hline Adj. for age & & -0.21 & & & 0.38 & 0.40 & \\
\hline and BMI & & 0.016 & & & $<0.001$ & $<0.001$ & \\
\hline
\end{tabular}

Values present the Spearman's correlation coefficients $(r)$ with significance level $(p)$. 
Table 2b. Spearman's correlations of DHEA(S) levels with anthropometric data, oGTT derived parameters, lipids and steroids in men.

\begin{tabular}{|c|c|c|c|c|c|c|c|c|c|c|c|c|}
\hline & \multicolumn{6}{|c|}{ Anthropometry } & \multicolumn{6}{|l|}{ oGTT } \\
\hline & age & waist & WHR & BMI & $\begin{array}{l}\text { Muscle } \\
\text { mass\% }\end{array}$ & $\begin{array}{l}\text { Fat } \\
\text { mass\% }\end{array}$ & $\begin{array}{l}\text { Gly } \\
\text { 30min. }\end{array}$ & $\begin{array}{l}\text { Gly } \\
60 \mathrm{~min} .\end{array}$ & $\begin{array}{l}\text { Cpep } \\
\text { 0min. }\end{array}$ & $\begin{array}{l}\text { Cpep } \\
60 \mathrm{~min} .\end{array}$ & $\begin{array}{l}\text { Ins } \\
\text { 0min. }\end{array}$ & $\begin{array}{l}\text { Ins } \\
60 \mathrm{~min} .\end{array}$ \\
\hline \multicolumn{13}{|l|}{ DHEA-S } \\
\hline Non- & -0.43 & & & & & & & & & & & \\
\hline adjust. & $p=<0.00 \mathrm{i}$ & & & & & & & & & & & \\
\hline Adj. for & & & 0.19 & & -0.16 & & 0.18 & 0.18 & 0.26 & 0.29 & 0.21 & 0.20 \\
\hline age & & & $p=0.02$ & & $p=0.05$ & & $p=0.03$ & $p=0.04$ & $p=0.001$ & $p<0.001$ & $p=0.01$ & $p=0.02$ \\
\hline Adj. for & & & & & & & 0.18 & 0.17 & 0.24 & 0.28 & 0.18 & 0.18 \\
\hline $\begin{array}{l}\text { age } \\
\text { and } B M I\end{array}$ & & & & & & & $p=0.03$ & $p=0.04$ & $p=0.003$ & $p<0.001$ & $p=0.03$ & $p=0.04$ \\
\hline \multicolumn{13}{|l|}{ DHEA } \\
\hline Non- & -0.49 & -0.32 & -0.23 & -0.29 & 0.17 & -0.18 & & & & -0.21 & & \\
\hline $\begin{array}{l}\text { adjust. } \\
\text { Adj. for } \\
\text { age }\end{array}$ & $p<0.001$ & $p<0.001$ & $p=0.006$ & $p<0.001$ & $p=0.04$ & $p=0.03$ & & & & $p=0.01$ & & \\
\hline Adj. for & & & 0.17 & & & & & & & & & \\
\hline $\begin{array}{l}\text { age } \\
\text { and } B M I\end{array}$ & & & $p=0.04$ & & & & & & & & & \\
\hline
\end{tabular}

\begin{tabular}{|c|c|c|c|c|c|c|c|c|c|c|c|c|c|}
\hline & \multicolumn{13}{|c|}{ Indices derived from oGTT } \\
\hline & \multicolumn{3}{|c|}{ HOMAF } & \multicolumn{2}{|c|}{ HOMAR } & \multicolumn{3}{|c|}{$\Sigma \operatorname{Ins}$} & \multicolumn{2}{|c|}{ Matsuda } & \multicolumn{3}{|c|}{ AUC gly/AUC ins } \\
\hline \multicolumn{14}{|l|}{ DHEA-S } \\
\hline Adj. for & & & & \multicolumn{2}{|c|}{0.18} & \multicolumn{3}{|c|}{0.20} & \multicolumn{2}{|c|}{-0.30} & \multicolumn{3}{|c|}{-0.25} \\
\hline age & & & & \multicolumn{2}{|c|}{$p=0.03$} & \multicolumn{3}{|c|}{$p=0.03$} & \multicolumn{2}{|c|}{$p=0.001$} & \multicolumn{3}{|c|}{$p=0.01$} \\
\hline $\begin{array}{l}\text { Adj.for } \\
\text { age }\end{array}$ & \multicolumn{3}{|c|}{0.18} & \multicolumn{2}{|c|}{0.21} & \multicolumn{3}{|c|}{0.22} & \multicolumn{2}{|c|}{-0.32} & \multicolumn{3}{|c|}{-0.27} \\
\hline & \multicolumn{3}{|l|}{ Lipids } & & & & \multicolumn{2}{|c|}{ Steroids } & \multicolumn{5}{|c|}{ Other parameters } \\
\hline & TG & T-CH & $\begin{array}{l}\text { HDL- } \\
\mathrm{CH}\end{array}$ & $\begin{array}{l}\text { LDL- } \\
\mathrm{CH}\end{array}$ & $\begin{array}{l}\text { FFA } \\
\text { 0min. }\end{array}$ & $\begin{array}{l}\text { FFA } \\
180 \text { min }\end{array}$ & SHBG & $\mathbf{T}$ & $\mathbf{A}$ & Leptin & IGF1 & TSH & $\begin{array}{l}\text { Adipo- } \\
\text { nectin }\end{array}$ \\
\hline \multicolumn{14}{|l|}{ DHEA-S } \\
\hline Non- & -0.17 & -0.27 & 0.17 & -0.27 & & & -0.24 & & & & & & \\
\hline adjust. & $p=0.04$ & $p=0.001$ & $p=0.04$ & $p=0.001$ & & & $p=0.003$ & & & & & & \\
\hline Adj. for & & & & & 0.22 & 0.18 & -0.33 & & & & & & \\
\hline age & & & & & $p=0.01$ & $p=0.04$ & $p<0.001$ & & & & & & \\
\hline $\begin{array}{l}\text { Adj. for } \\
\text { age } \\
\text { and BMI }\end{array}$ & & & & & $\begin{array}{l}0.23 \\
p=0.01\end{array}$ & $\begin{array}{l}0.20 \\
p=0.03\end{array}$ & $\begin{array}{l}-0.31 \\
p<0.001\end{array}$ & & & & & & \\
\hline \multicolumn{14}{|l|}{ DHEA } \\
\hline Non- & -0.28 & -0.29 & 0.22 & -0.29 & & & & 0.20 & 0.35 & -0.21 & 0.22 & 0.23 & 0.28 \\
\hline $\begin{array}{l}\text { adjust. } \\
\text { Adj. for }\end{array}$ & $p<0.001$ & $p<0.001$ & $p=0.008$ & $p<0.001$ & & & & $p=0.02$ & $\begin{array}{c}p<0.001 \\
0.30\end{array}$ & $p=0.03$ & $p=0.01$ & $p=0.005$ & $\begin{array}{c}p=0.008 \\
0.25\end{array}$ \\
\hline age & & & & & & & & & $p<0.001$ & & & & $p=0.02$ \\
\hline $\begin{array}{l}\text { Adj. for } \\
\text { age } \\
\text { and } B M I\end{array}$ & & & & & & & & & $\begin{array}{c}0.31 \\
p<0.001\end{array}$ & & & & $\begin{array}{c}0.23 \\
p=0.03\end{array}$ \\
\hline
\end{tabular}

Values present the Spearman correlation coefficients $(r)$ with significance level $(p)$. 
Men (Table 2b): DHEA levels correlated negatively to age $(p<0.001)$, BMI $(p<0.001)$, waist circumference $(\mathrm{p}<0.001)$, WHR $(\mathrm{p}<0.01)$ and $\%$ fat mass $(p<0.05)$, and positively to $\%$ muscle mass $(p<0.05)$. In contrast to the results found in women, there was no correlation to fasting or stimulated levels of glucose, insulin and C-peptide (except for Cpep0, $\mathrm{p}<0.01$ ), or to oGTT derived indices of insulin sensitivy and secretion. Positive correlation of DHEA and HDL-CH $(p<0.01)$ and negative correlations to total-CH $(\mathrm{p}<0.001), \quad \mathrm{TG}$ $(p<0.001)$ and LDL-CH $(p<0.001)$ were found. For steroids, there were positive correlations to $\mathrm{T}(\mathrm{p}<0.05), \mathrm{A}$ $(p<0.001)$. Positive correlations of DHEA to IGF1 $(p<0.01)$, TSH $(p<0.01)$ and adiponectin $(p<0.01)$ were found. Leptin and DHEA correlated negatively $(p<0.05)$. Non-adjusted DHEA-S correlated negatively only to age $(\mathrm{p}<0.001)$ and to TG $(\mathrm{p}<0.05)$, total-CH $(\mathrm{p}<0.001)$, LDL$\mathrm{CH} \quad(\mathrm{p}<0.001)$ and SHBG $(\mathrm{p}<0.01)$; it correlated positively to HDL-CH $(\mathrm{p}<0.05)$.

Partial correlations of DHEA(S) levels to anthropometric data, oGTT derived parameters, lipids and steroids after adjustment for age or age and BMI

The data analysis revealed strong dependence of DHEA(S) levels on age and BMI, and the parameters were thus adjusted for these covariates.

Women (Table 2a): The correlations of DHEA to anthropometric parameters and oGTT derived data disappeared after adjustment for age. Adjusted DHEA still correlated negatively to LDL-CH in the COC nonusers. These correlations were not found in COC users. Strong positive correlations of DHEA to testosterone $(p<0.001)$ and androstendione $(p<0.001)$ persisted even after adjustment.

For DHEA-S, age-adjustment revealed a positive correlation to waist circumference $(p<0.05)$, BMI $(p<0.01)$ and WHR $(p<0.05)$. Analysis revealed a positive correlation of adjusted DHEA-S to fasting free fatty acids (FFA0) in both subgroups $(\mathrm{p}<0.05)$. Total-CH and TG did not correlate to either adjusted or unadjusted DHEA$S$ regardless of COC. No correlation of adjusted DHEA-S to oGTT data was found for the women without COC. In the subgroup of women using COC, however, the positive correlations of DHEA-S to fasting and stimulated C-peptide and insulin levels, as well as a negative correlation to insulin sensitivity, remained significant even after the adjustment (all $\mathrm{p}<0.01$ ). The positive correlation of adjusted DHEA-S to testosterone $(p<0.001)$ and the negative correlation of DHEA-S to
SHBG persisted $(\mathrm{p}<0.001)$ in women that did not use COC.

Men (Table 2b): The correlations of DHEA to anthropometric parameters and oGTT derived data disappeared after adjustment for age. DHEA did not correlate to lipids, SHBG or testosterone, but the positive correlations to androstendione $(\mathrm{p}<0.001)$ and adiponectin $(\mathrm{p}<0.05)$ remained significant.

After adjustment for age, DHEA-S levels correlated positively to WHR $(p<0.05)$, stimulated glucose $(\mathrm{p}<0.05)$, fasting $(\mathrm{p}<0.01)$ and stimulated insulin $(\mathrm{p}<0.05)$ and $\mathrm{C}$-peptide levels $(\mathrm{p}<0.001)$. As with women using COC, adjusted DHEA-S negatively correlated to insulin sensitivity (1/HOMA R, $p<0.05$; Matsuda, $\mathrm{p}<0.001 ; \quad$ FGIR, $\mathrm{p}<0.05 ; \quad$ SUM ins, $\mathrm{p}<0.05$, AUCgly/AUCins, $p<0.05$ ). No correlations to steroid hormones or to lipids were found, with the exception of a positive correlation of DHEA-S to FFA0 $(\mathrm{p}<0.05)$ and FFA180 $(\mathrm{p}<0.05)$ of the oGTT. The negative correlation of DHEA-S to SHBG remained significant $(\mathrm{p}<0.001)$.

\section{Discussion}

A set of data describing the anthropometric and metabolic status of the healthy offspring of DM2 patients and controls has been collected; the authors have tried to test some correlations of the obtained variables to DHEA and DHEA-S levels, and to evaluate in particular their relationship to obesity and body fat distribution, insulin resistance and lipid spectra.

\section{DHEA(S), obesity and body fat distribution}

Obesity and body fat distribution (especially abdominal adiposity) are well-known risk factors associated with many diseases of the developed world; they are also associated with dyslipidemia and insulin resistance (Despres et al. 1989). Sex steroid hormones in both males and females have been closely linked to the regulation of adiposity, through either direct or indirect mechanisms. Tchernof and Despres (2000) have suggested that the intracrine conversion of DHEA to active androgens - which are involved in direct adipocyte physiology, body fat accretion and regional fat distribution - may be a significant factor in the association of DHEA with obesity and abdominal fat accumulation. The differences between males and females in the influence of DHEA on various androgendependent parameters can be explained by the fact that in women a greater proportion of the circulating androgens 
is derived from DHEA. In both men and women, most studies found that elevated plasma levels of DHEA were associated with reduced obesity, esp. abdominal (Couillard et al. 2000, Tchernof et al. 1995).

In intervention studies, data from animal studies have supported the beneficial effect of DHEA pharmacological treatment on body composition and insulin sensitivity (Han et al. 1998). The majority of intervention trials evaluating body composition and body fat distribution after DHEA treatment in humans, however, have found no effect even when using supraphysiological doses of DHEA, as reviewed by (Tchernof and Labrie 2004).

The authors found negative correlations of nonadjusted DHEA level to BMI, WHR, waist circumference and fat mass, in both genders, but after adjustment for age and BMI these correlations disappeared - as was the case in (Kunešová et al. 2002).

The data regarding DHEA-S is much more controversial - some studies have found a negative correlation to total adiposity in men (Couillard et al. 2000, Abbasi et al. 1998, Pritchard et al. 1998) and in premenopausal women (Ivandic et al. 1998), others have found a positive correlation only in men (Tchernof et al. 1995), and yet others no correlation in men (Vettor et al. 1997) or women (Maccario et al. 1999). For body fat distribution, there are also discrepant results in published literature: in men, negative (Couillard et al. 2000, Abbasi et al. 1998, Haffner et al. 1994), no (Pritchard et al. 1998) or positive (Tchernof et al. 1995) correlations to DHEA-S; in women, negative (premenopausal: Ivandic et al. 1998, De Pergola et al. 1996; postmenopausal: Abbasi et al. 1998), no (Maccario et al. 1999) or positive (Barrett-Connor and Ferrara 1996) correlations to DHEAS. Age differences in the populations studied may be the confounding factor here, as most of the associations presented were not adjusted for age.

In this study, the results for both males and females support the existence of no correlation between non-adjusted DHEA-S and anthropometric parameters. After adjustment for age, however, significant, positive correlations were obtained of DHEA-S to BMI, WHR and waist circumference in women, and to WHR in men. Apparent paradoxical increase of DHEA-S levels in obese subjects may be explained by decreased activity of (ubiquitous) peripheral steroid sulphatase, an enzyme converting DHEA-S to biologically active unconjugated DHEA (Kř́̌ž et al. 2007), believed to function as an antiobese factor (Tchernof and Labrie 2004).

\section{DHEA(S), insulin resistance and hyperinsulinemia}

There is evidence from human cross-sectional studies that DHEA levels are decreased in diabetic patients and in people with impaired glucose tolerance and insulin resistance (Kameda et al. 2005). A negative relationship between steroid hormones and insulin and glycemic responses to an oral glucose load has been found in several studies (Tchernof et al. 1995, Haffner et al. 1994, Vasarhelyi et al. 2003).

It has been suggested that plasma DHEA(S) levels are more closely associated with total and abdominal adiposity than with indices of glucose-insulin homeostasis (Tchernof et al. 1995). Nevertheless, there are several proposed mechanisms explaining associations between DHEA(S) and insulin action which are beyond the scope of this article. On the other hand, there have also been studies that did not confirm this negative correlation of DHEA(S) to insulin levels or insulin resistance (Saruc et al. 2003, Kauffman et al. 2006, Golden et al. 2007). There are also discrepancies in the results of intervention trials: exogenous treatment with DHEA markedly improved insulin sensitivity and lipid spectrum in postmenopausal women with symptoms of metabolic syndrome (Lasco et al. 2001), but showed no effect on metabolic compensation in females with adrenal insufficiency (Christiansen et al. 2005) or in elderly subjects (Nair et al. 2006, Basu et al. 2007).

The authors have found a negative correlation of non-adjusted DHEA levels to fasting and oGTT stimulated glucose levels in women that did not use the hormonal contraception. In neither women using hormonal contraception, nor in men were these correlations apparent. After adjustment for age and for age and BMI, all of the aforementioned correlations disappeared. Insulin and C-peptide levels during oGTT did not correlate to DHEA levels.

No correlation of DHEA-S levels with oGTT derived data (except for a weak negative correlation to glucose levels) in women without $\mathrm{COC}$ was found. In men, non-adjusted DHEA-S levels did not correlate to insulin sensitivity or glucose tolerance, as was shown by Abate et al. (2002), but after adjustment for age or age and BMI it correlated positively to fasting and stimulated glucose, insulin and C-peptide, and negatively to insulin sensitivity. Similar results were obtained from women using $\mathrm{COC}$, regardless of age or age and BMI adjustment.

\section{DHEA(S) and lipid spectra}

The relationship between endogenous DHEA(S) 
and plasma lipids and lipoproteins has been examined in many studies, mainly supporting the correlation of DHEA(S) to favorable lipid spectra (Haffner et al. 1993). Our findings confirm the negative correlations of nonadjusted DHEA(S) to triacylglycerols, total cholesterol and LDL-CH, especially in men. However, these negative correlations disappeared after adjustment for age or age and BMI (as in Tchernof et al. 1997). Only the negative correlation of DHEA to LDL-CH levels persisted after the adjustments in women without COC. The positive correlation of DHEA(S) to HDL-CH also disappeared after adjustment. On the other hand, positive correlations of adjusted DHEA-S to fasting FFA in both sexes were found. In recent studies the relation between fatty acid metabolism and androgens was documented (Bruder et al. 2006, Mai et al. 2006, Tang et al. 2007).

Statistical analysis revealed that almost all correlations of DHEA or DHEA-S to adiposity and fat distribution in men as well as in women disappeared after adjustment for age and for age and BMI. There are, however, differences between men and women in the correlations of $\operatorname{DHEA}(\mathrm{S})$ to insulin sensitivity, lipid levels and other steroid hormones. The administration of hormonal contraceptives must also be kept in mind. In this respect the benefits of DHEA(S) supplementation seem, at least in terms of its alleged antiobesity and antidiabetogenic effects, more than controversial.

\section{Conflict of Interest}

There is no conflict of interest.

\section{Acknowledgements}

We would like to thank all the subjects who participated in this study and all our colleagues for excellent nurse and laboratory assistance. Supported by grant IGA MH CR NR/7809-5.

\section{References}

ABATE N, HAFFNER SM, GARG A, PESHOCK RM, GRUNDY SM: Sex steroid hormones, upper body obesity, and insulin resistance. J Clin Endocrinol Metab 87: 4522-4527, 2002.

ABBASI A, DUTHIE EH, SHELDAHL L, WILSON C, SASSE E, RUDMAN I: Association of dehydroepiandrosterone sulfate, body composition, and physical fitness in independent community-dwelling older men and women. J Am Geriatr Soc 46: 263-273, 1998.

BARRETT-CONNOR E, FERRARA A: Dehydroepiandrosterone, dehydroepiandrosterone sulfate, obesity, waist-hip ratio, and noninsulin-dependent diabetes in postmenopausal women: the Rancho Bernardo Study. J Clin Endocrinol Metab 81: 59-64, 1996.

BASU R, MAN CD, CAMPONI M, BASU A, NAIR KS, JENSEN MD, KHOSLA S, KLEE G, TOFFOLO G, COBELLI C, RIZZA RA: Two years of treatment with dehydroepiandrosterone does not improve insulin secretion, insulin action, or postprandial glucose turnover in elderly men or women. Diabetes 56: 753-766, 2007.

BAULIEU EE, THOMAS G, LEGRAIN S, LAHLOU N, ROGER M, DEBUIRE B, FAUCOUNAU V, GIRARD L, HERVY MP, LATOUR F, LEAUD MC, MOKRANE A, PITTI-FERRANDI H, TRIVALLE C, DE LACHARRIERE O, NOUVEAU S, RAKOTO-ARISON B, SOUBERBIELLE JC, RAISON J, LE BOUC Y, RAYNAUD A, GIRERD X, FORETTE F: Dehydroepiandrosterone (DHEA), DHEA sulfate, and aging: contribution of the DHEAge Study to a sociobiomedical issue. Proc Natl Acad Sci USA 97: 4279-4284, 2000.

BLÁHA P: ANTROPO - ein Programm fuer automatische Bearbeitung anthropologischer Daten. Wiss Z HumboldtUniv Berl 5: 153-156, 1991.

BRUDER ED, RAFF H, GOODFRIEND TL: An oxidized derivative of linoleic acid stimulates dehydroepiandrosterone production by human adrenal cells. Horm Metab Res 38: 803-806, 2006.

CAMERON DR, BRAUNSTEIN GD: The use of dehydroepiandrosterone therapy in clinical practice. Treat Endocrinol 4: 95-114, 2005.

CELEC P, STÁRKA L: Dehydroepiandrosterone - is the fountain of youth drying out? Physiol Res 52: 397-407, 2003.

CHRISTIANSEN JJ, GRAVHOLT CH, FISKER S, MOLLER N, ANDERSEN M, SVENSTRUP B, BENNETT P, IVARSEN P, CHRISTIANSEN JS, JORGENSEN JO: Very short term dehydroepiandrosterone treatment in female adrenal failure: impact on carbohydrate, lipid and protein metabolism. Eur J Endocrinol 152: 77-85, 2005. 
COUILLARD C, GAGNON J, BERGERON J, LEON AS, RAO DC, SKINNER JS, WILMORE JH, DESPRES JP, BOUCHARD C: Contribution of body fatness and adipose tissue distribution to the age variation in plasma steroid hormone concentrations in men: the HERITAGE Family Study. J Clin Endocrinol Metab 85: 10261031, 2000.

DE PERGOLA G, ZAMBONI M, SCIARAFFIA M, TURCATO E, PANNACCIULLI N, ARMELLINI F, GIORGINO F, PERRINI S, BOSELLO O, GIORGINO R: Body fat accumulation is possibly responsible for lower dehydroepiandrosterone circulating levels in premenopausal obese women. Int J Obes Relat Metab Disord 20: 1105-1110, 1996.

DESPRES JP, MOORJANI S, FERLAND M, TREMBLAY A, LUPIEN PJ, NADEAU A, PINAULT S, THERIAULT G, BOUCHARD C: Adipose tissue distribution and plasma lipoprotein levels in obese women. Importance of intra-abdominal fat. Arteriosclerosis 9: 203-210, 1989.

GOLDEN SH, DOBS AS, VAIDYA D, SZKLO M, GAPSTUR S, KOPP P, LIU K, OUYANG P: Endogenous sex hormones and glucose tolerance status in postmenopausal women. J Clin Endocrinol Metab 92: 1289-1295, 2007.

HAFFNER SM, MYKKANEN L, VALDEZ RA, KATZ MS: Relationship of sex hormones to lipids and lipoproteins in nondiabetic men. J Clin Endocrinol Metab 77: 1610-1615, 1993.

HAFFNER SM, KARHAPAA P, MYKKANEN L, LAAKSO M: Insulin resistance, body fat distribution, and sex hormones in men. Diabetes 43: 212-219, 1994.

HAMPL R, STÁRKA L: Dehydroepiandrosterone, "the youth hormone", in the light of recent findings. [In Czech] Cas Lek Cesk 137: 8-12, 1998.

HAMPL R, STÁRKA L, JANSKÝ L: Steroids and thermogenesis. Physiol Res 55: 123-131, 2006.

HAMPL R, ŠULCOVÁ J, BÍLEK R, HILL M: How short-term transdermal treatment of men with 7-oxodehydroepiandrosterone influence thyroid function. Physiol Res 55: 49-54, 2006.

HAN DH, HANSEN PA, CHEN MM, HOLLOSZY JO: DHEA treatment reduces fat accumulation and protects against insulin resistance in male rats. J Gerontol A Biol Sci Med Sci 53: B19-24, 1998.

IVANDIC A, PRPIC-KRIZEVAC I, SUCIC M, JURIC M: Hyperinsulinemia and sex hormones in healthy premenopausal women: relative contribution of obesity, obesity type, and duration of obesity. Metabolism 47: 13-19, 1998.

KAMEDA W, DAIMON M, OIZUMI T, JIMBU Y, KIMURA M, HIRATA A, YAMAGUCHI H, OHNUMA H, IGARASHI M, TOMINAGA M, KATO T: Association of decrease in serum dehydroepiandrosterone sulfate levels with the progression to type 2 diabetes in men of a Japanese population: the Fungata Study. Metabolism 54: 669-676, 2005.

KAUFFMAN RP, BAKER VM, DIMARINO P, CASTRACANE VD: Hyperinsulinemia and circulating dehydroepiandrosterone sulfate in white and Mexican American women with polycystic ovary syndrome. Fertil Steril 85: 1010-1016, 2006.

KŘIIŽ L, BIČÍKOVÁ M, HAMPL R: Roles of steroid sulfatase in brain and other tissues, Physiol Res 2007 [In press].

KROBOTH PD, SALEK FS, PITTENGER AL, FABIAN TJ, FRYE RF: DHEA and DHEA-S: a review. $J$ Clin Pharmacol 39: 327-348, 1999.

KUNEŠOVÁ M, HAINER V, OBENBERGER J, MIKULOVÁ R, PAŘÍZKOVÁ J, SLABÁ S, BEZDIČKOVÁ D, SEIDL Z: Adipose tissue distribution in obese females. Relationship to androgens, cortisol, growth hormone and leptin. [In Czech] Sb Lek 103: 477-485, 2002.

LABRIE F: Intracrinology. Mol Cell Endocrinol 78: C113-C118, 1991.

LASCO A, FRISINA N, MORABITO N, GAUDIO A, MORINI E, TRIFILETTI A, BASILE G, NICITA-MAURO V, CUCINOTTA D: Metabolic effects of dehydroepiandrosterone replacement therapy in postmenopausal women. Eur J Endocrinol 145: 457-461, 2001.

MACCARIO M, MAZZA E, RAMUNNI J, OLEANDRI SE, SAVIO P, GROTTOLI S, ROSSETTO R, PROCOPIO M, GAUNA C, GHIGO E: Relationships between dehydroepiandrosterone-sulphate and anthropometric, metabolic and hormonal variables in a large cohort of obese women. Clin Endocrinol (Oxf) 50: 595-600, 1999. 
MAI K, BOBBERT T, KULLMANN V, ANDRES J., ROCHLITZ H, OSTERHOFF M, WEICKERT MO, BAHR V, MOHLING M, PFEIFFER AF, DIEDERICH S, SPRANGER J: Free fatty acids increase androgen precursors in vivo. J Clin Endocrinol Metab 91: 1501-1507, 2006.

MATSUDA M, DEFRONZO RA: Insulin sensitivity indices obtained from oral glucose tolerance testing: comparison with the euglycemic insulin clamp. Diabetes Care 22: 1462-1470, 1999.

MATTHEWS DR, HOSKER JP, RUDENSKI AS, NAYLOR BA, TREACHER DF, TURNER RC: Homeostasis model assessment: insulin resistance and beta-cell function from fasting plasma glucose and insulin concentrations in man. Diabetologia 28: 412-419, 1985.

NAIR KS, RIZZA RA, O’BRIEN P, DHATARIYA K, SHORT KR, NEHRA A, VITTONE JL, KLEE GG, BASU A, BASU R, COBElli C, TOFFOLO G, DALlA MAN C, TINDALl DJ, MELTON LJ, $3^{\text {RD }}$, SMITH GE, KHOSLA S, JENSEN MD: DHEA in elderly women and DHEA or testosterone in elderly men. $N$ Engl J Med 355: 1647-1659, 2006.

NESTLER JE, BARLASCINI CO, CLORE JN, BLACKARD WG: Dehydroepiandrosterone reduces serum low density lipoprotein levels and body fat but does not alter insulin sensitivity in normal men. $J$ Clin Endocrinol Metab 66: 57-61, 1988.

PRITCHARD J, DESPRES JP, GAGNON J, TCHERNOF A, NADEAU A, TREMBLAY A, BOUCHARD C: Plasma adrenal, gonadal, and conjugated steroids before and after long-term overfeeding in identical twins. $J$ Clin Endocrinol Metab 83: 3277-3284, 1998.

SARUC M, YUCEYAR H, AYHAN S, TURKEL N, TUZCUOGLU I, CAN M: The association of dehydroepiandrosterone, obesity, waist-hip ratio and insulin resistance with fatty liver in postmenopausal women-a hyperinsulinemic euglycemic insulin clamp study. Hepatogastroenterology 50: 771-774, 2003.

ŠULCOVÁ J, HILL M, HAMPL R, STÁRKA L: Age and sex related differences in serum levels of unconjugated dehydroepiandrosterone and its sulphate in normal subjects. J Endocrinol 154: 57-62, 1997.

TANG X, MA H, ZOU S, CHEN W: Effects of dehydroepiandrosterone (DHEA) on hepatic lipid metabolism parameters and lipogenic mRNA expression in broiler chickens. Lipids 42: 1025-1033, 2007.

TCHERNOF A, DESPRES JP, BELANGER A, DUPONT A, PRUD'HOMME D, MOORJANI S, LUPIEN PJ, LABRIE F: Reduced testosterone and adrenal C19 steroid levels in obese men. Metabolism 44: 513-519, 1995.

TCHERNOF A, DESPRES JP: Sex steroid hormones, sex hormone-binding globulin, and obesity in men and women. Horm Metab Res 32: 526-536, 2000.

TCHERNOF A, LABRIE F: Dehydroepiandrosterone, obesity and cardiovascular disease risk: a review of human studies. Eur J Endocrinol 151: 1-14, 2004.

TCHERNOF A, LABRIE F, BELANGER A, PRUD'HOMME D, BOUCHARD C, TREMBLAY A, NADEAU A, DESPRES JP: Relationships between endogenous steroid hormone, sex hormone-binding globulin and lipoprotein levels in men: contribution of visceral obesity, insulin levels and other metabolic variables. Atherosclerosis 133: 235-244, 1997.

VASARHELYI B, BENCSIK P, TRESZL A, BARDOCZY Z, TULASSAY T, SZATHMARI M: The effect of physiologic hyperinsulinemia during an oral glucose tolerance test on the levels of dehydroepiandrosterone (DHEA) and its sulfate (DHEAS) in healthy young adults born with low and with normal birth weight. Endocr J 50: 689-695, 2003.

VETTOR R, DE PERGOLA G, PAGANO C, ENGLARO P, LAUDADIO E, GIORGINO F, BLUM WF, GIORGINO R, FEDERSPIL G: Gender differences in serum leptin in obese people: relationships with testosterone, body fat distribution and insulin sensitivity. Eur J Clin Invest 27: 1016-1024, 1997.

VILLAREAL DT, HOLLOSZY JO: Effect of DHEA on abdominal fat and insulin action in elderly women and men: a randomized controlled trial. JAMA 292: 2243-2248, 2004.

VRBÍKOVÁ J, HILL M, STÁRKA L, CIBULA D, BENDLOVÁ B, VONDRA K, ŠULCOVÁ J, ŠNAJDEROVÁ M: The effects of long-term metformin treatment on adrenal and ovarian steroidogenesis in women with polycystic ovary syndrome. Eur J Endocrinol 144: 619-628, 2001.

WELLE S, JOZEFOWICZ R, STATT M: Failure of dehydroepiandrosterone to influence energy and protein metabolism in humans. $J$ Clin Endocrinol Metab 71: 1259-1264, 1990. 